\title{
sciendo
}

DOI 10.2478/sbe-2018-0024

SBE no. 13(2) 2018

\section{THE IMPACT OF THE ASIAN CRISIS ON GOVERNANCE: DOES OECD MEMBERSHIP OR INCOME LEVELS MATTER?}

\author{
KAYA Halil Dincer \\ Northeastern State University, United States
}

\begin{abstract}
:
We examine the impact of the 1997 Asian Crisis on governance. We look into how the crisis affected High-Income OECD, High-Income Non-OECD, Upper-middle Income, LowerMiddle Income, and Low Income Countries. For measures of governance, we use the World Bank's Governance Indicators dataset which includes six measures of governance. We find that pre- and post-crisis, the ranking of each income group has not changed except for year 2004 when the High-Income Non-OECD Countries surpassed the High-Income OECD Countries in "Political Stability and Absence of Violence" category. In other words, our results show that, other than that exception in 2004, both pre- and post-crisis, the High-Income OECD Countries had the best governance measures, the High-Income Non-OECD Countries had the second best measures, and so on, in the order shown above. One point to note here: The High-Income NonOECD Countries performed much better than the other groups after year 1998. After 1998, this group improved in all six dimensions of governance. We conclude that although crises affect all income groups, because of certain characteristics of the High-Income Non-OECD group, they tend to better react to crises.
\end{abstract}

Key words: Governance, Asian Crisis, WGI, Economic Crisis

\section{Introduction}

In this study, we examine the impact of a major financial crisis, the 1997 Asian Crisis on governance. We look into how OECD membership affects the crisis' impact on governance. We also look into how countries' income levels affect the crisis' impact on governance.

Several previous studies like Haggard (1999), Jung (2010), and Levine (2012) examine the impact of a crisis like the 1997 Asian Crisis or the 2008-2009 Global Crisis on governance. Haggard (1999) examine the impact of the Asian Crisis and contends that the political regime type, the structure of business-government relations, and the 
design of government agencies are the main factors that determine how governance is affected by a crisis. Jung (2010), on the other hand, discusses the roles of path dependence, centralization or decentralization, politicization, coordination and coherence (or retention of power by individual ministries or agencies), and time perspective on the disruption of the stability of public administration due to crises. Levine (2012) sees the problem as a systemic failure of financial regulation, therefore he recommends the formation of a new independent institution with informed, expert staff.

We make three contributions in this study. First, all of these previous studies focus on a particular region or on a group of countries. Here, we examine the impact on all of the countries in the world (as much as our dataset allows). Our second contribution is to show how OECD membership affects a crisis' impact on governance. Do Non-OECD countries like Saudi Arabia insulate themselves from such crises? Our third contribution is to show how a country's income level affects a crisis' impact on that country's governance.

In our analyses, we use the World Bank's Worldwide Governance Indicators (i.e. WGI) dataset. This dataset covers governance data for 215 countries. The WGI dataset covers six indicators of governance. These are "Voice and Accountability", Political Stability and Absence of Violence", "Government Effectiveness", "Regulatory Quality", "Rule of Law", and "Control of Corruption".

World Bank classifies countries according to their OECD membership and also according to the country's income levels. We use their classification and focus on five groups of countries. These are High-Income OECD, High-Income Non-OECD, Uppermiddle Income, Lower-Middle Income, and Low Income Countries.

The paper proceeds as follows: Section 2 discusses the previous literature. Section 3 states our hypotheses. Section 4 explains our data. Section 5 shows the results. Finally, Section 6 concludes.

\section{Literature Review}

In one of the earlier studies, Remmer (1990) examines the relation between democracy and economic crisis. According to Remmer (1990), if the magnitude of the debt burden at the outbreak of the crisis is controlled, there is no statistically significant difference between democratic and authoritarian regimes, or between new democracies and more established regimes in terms of the impact of the crisis.

Higgott (1998) examines the Asian crisis. Higgott (1998) argues that Japan had a significant role as a "long-term" and "ever-present" factor in the crisis. Higgott (1998) also explains the resistance of the Asian countries' economic development models to conform with the Western economic system.

Haggard (1999) also focuses on the East Asian financial crisis of 1997-98. Haggard (1999) examines the role of political regime type, the structure of business- 
government relations, and the design of government agencies, and contends that institutional weaknesses contributed to the onset of the Asian financial crisis.

Later, Li (2003) establishes a theory of relation-based governance to explain both the "East Asian miracle" and the Asian crisis. According to Li (2003), "economic development is fundamentally a process of establishing relation-based governance and subsequently making a transition to rule-based governance". Li (2003) contends that "there is little difference between East and West or between North and South other than they are at different stages of development".

Fleischer and Parrado (2010) examine the impact of the 2008-2009 crisis on executive decision-making in Spain and Germany. The authors argue that, during this period, while both countries experienced a centralization of executive decision making, this was less pronounced in Germany due to its institutional setting. Fleischer and Parrado (2010) explains that this was due to the Chancellor's authority being more limited compared to the Spanish Prime Minister's in cabinet.

Woods (2010) examines IMF's role after the crises and argues that the IMF's dependence on loans from its wealthiest members restrains it from serious reform. The author recommends IMF to get more resources, especially from emerging economies.

Jung (2010) argues that the global financial crisis that began in 2008 has had a significant impact on public administration in most countries in the world. According to Jung (2010), "Different countries, experiencing the current economic crisis in different ways, have chosen different options within these dichotomies, with varying levels of success".

Later, Peters, Pierre, and Randma-Liiv (2011) argue that countries like Germany or Sweden were at different starting points in their governance regimes when the crisis hits when compared to the U.S., therefore the policy and governance options available to them were very different. The authors also point out to the fact that there have been no common ideas globally about how best to govern.

Another study that examines the impact of this recent global crisis is Gieve and Provost (2012). The authors argue that policymakers' objective of keeping inflation low and stable while employing some regulation to financial markets caused a lack of coordination between monetary and regulatory policy in the subprime mortgage market. Gieve and Provost (2012) recommend better coordination between monetary and regulatory policymakers in the future.

Levine (2012) argues that "there was a systemic failure of financial regulation and that senior policymakers repeatedly enacted and implemented policies that destabilized the global financial system". The author recommends a new independent institution with informed, expert staff which will evaluate financial regulation from the public's viewpoint.

Posner and Blöndal (2012) contends that "politics is far less predictable and decision making far more open than ever before. The magnitude of the fiscal challenges has heightened the importance of early action and foresight in fiscal policymaking". According to the author, "the best chance of effectively dealing with the 
fiscal forces building up is to make timely decisions that have the broad support of as many interests and actors as possible".

Kickert (2012) analyzes how the UK, Germany and the Netherlands responded to the crisis. According to the author, the crisis "resulted in the centralization of decision making in the hands of prime-minister and Finance ministers across the three nations, though the extent of prime-ministerial power differed between the countries. The subsequent stages of the crisis involved many more ministries, parliaments, politicians, parties, and social partners in deliberation and decision making". Kickert (2012) contends that economic recovery requires more politicized decision-making.

Desta (2012) examines African countries' development issues. The author argues that the development experts and policy makers suggest the application of East Asian developmental state model to African countries. The author asks why Africa is used as testing ground for a number of development models forged mainly to satisfy western donors.

Another study that examines an African country is Mgonja and Tundui (2012) study. Mgonja and Tundui (2012) examine Tanzanian government's ambitious and farreaching reform programs to improve the socioeconomic condition of the country since 1990s. The authors contend that unless someone addresses "institutional shortfalls" within the greater system of governance, any policy or reform initiative aimed at improving good governance will ultimately fail to deliver.

Kahler (2013) argues that international cooperation was better after the 20082009 crisis compared to the two previous big crises (i.e. the Great Depression of 192933 and the global recession of 1981-82). According to Kahler (2013), this departure from previous responses to economic crisis are due to several different factors. The character of economic globalization was different this time (i.e. economic nationalism was less attractive this time due to global economic integration). Also this time, there were combined international constraints imposed by international economic cooperation. Another important factor this time was the major developing and transitional economies being more successful during the crisis. Kahler (2013) recommends that national policies should be scrutinized more closely in the future. He also recommends the international constraints to be stricter. He warns us about the role of key emerging economies, such as China, India, and Brazil on global governance.

As summarized above, the previous literature does not focus on the effect of OECD membership or the effect of a country's income level on a crisis' impact on governance. Here, we attempt to show how these two factors alter the relation between a financial crisis and governance. The previous literature also focuses on a certain country or region. Here, our tests cover 213 countries in the world. So, it is bigger in its scope. 


\section{Hypotheses}

Some Non-OECD countries like Saudi Arabia and Bahrain tend to be more authoritarian and more resource-rich countries, therefore it should be easier for them to defend themselves in the face of a crisis. Other Non-OECD countries are more isolated, smaller countries (like Andorra, Aruba, and the Bahamas) that can better alleviate the effects of a crisis on public governance. Therefore, our first hypothesis is as follows:

Hypothesis 1: The impact of a financial crisis is less severe on Non-OECD countries' governance than on OCED countries' governance.

Our second hypothesis deals with the effects of a country's income level on the impact of a crisis. We expect that, due to their additional resources, higher income countries should better protect themselves from the effects of a crisis. Therefore, our second hypothesis is as follows:

Hypothesis 2: The impact of a financial crisis is much more severe on Poorer countries' governance than on Richer countries' governance.

Since we have High Income, Upper-Middle Income, Lower-Middle Income, and Low Income groups in this study, we expect High Income countries to perform better than Upper-Middle Income countries, Upper-Middle Income countries to perform better than Lower-Middle Income countries, and Lower-Middle Income countries to perform better than Low Income Countries.

\section{Data and Methodology}

In this study, in order to examine the impact of the Asian Crisis on HighIncome and Low-Income Countries' governance policies, we use World Bank's Worldwide Governance Indicators dataset. This dataset includes six measures of governance. These are "Voice and accountability", "Political stability and absence of violence", "Government effectiveness", "Regulatory quality", "Rule of law", and "Control of corruption".

There are 215 countries in the dataset. The governance data are annual data and they are posted on the website www.govindicators.org. We examine the period from 1996 through 2005.

The six governance measures and their definitions (as given by World Bank) are shown below:

Voice and Accountability:

Reflects perceptions of the extent to which a country's citizens are able to participate in selecting their government, as well as freedom of expression, freedom of association, and a free media.

Political Stability and Absence of Violence: 
Reflects perceptions of the likelihood that the government will be destabilized or overthrown by unconstitutional or violent means, including politically-motivated violence and terrorism.

Government Effectiveness:

Reflects perceptions of the quality of public services, the quality of the civil service and the degree of its independence from political pressures, the quality of policy formulation and implementation, and the credibility of the government's commitment to such policies.

Regulatory Quality:

Reflects perceptions of the ability of the government to formulate and implement sound policies and regulations that permit and promote private sector development.

Rule of Law:

Reflects perceptions of the extent to which agents have confidence in and abide by the rules of society, and in particular the quality of contract enforcement, property rights, the police, and the courts, as well as the likelihood of crime and violence.

Control of Corruption:

Reflects perceptions of the extent to which public power is exercised for private gain, including both petty and grand forms of corruption, as well as "capture" of the state by elites and private interests.

For all six dimensions of governance, the estimate of governance (i.e. the score) ranges from approximately -2.5 (weak) to 2.5 (strong) governance performance.

Table 1 shows each group of countries' (based on World Bank's country income groups) governance scores from 1996 to 2005.

Table 1. World Governance Indicators across Income Groups

\begin{tabular}{|c|c|c|c|c|c|c|}
\hline & Year & H-OECD & H-NonOECD & Low & LowerMiddle & UpperMiddle \\
\hline \multirow[t]{7}{*}{ Voice and Acc. } & 1996 & 1.35 & 0.47 & -1.03 & -0.51 & -0.13 \\
\hline & 1998 & 1.33 & 0.53 & -0.98 & -0.53 & -0.05 \\
\hline & 2000 & 1.34 & 0.50 & -1.05 & -0.44 & -0.27 \\
\hline & 2002 & 1.28 & 0.52 & -0.95 & -0.52 & -0.03 \\
\hline & 2003 & 1.29 & 0.61 & -1.09 & -0.50 & 0.04 \\
\hline & 2004 & 1.45 & 0.58 & -1.14 & -0.45 & 0.03 \\
\hline & 2005 & 1.42 & 0.64 & -0.96 & -0.42 & -0.02 \\
\hline \multirow[t]{7}{*}{ Political Stab. } & 1996 & 1.18 & 0.44 & -0.99 & -0.48 & -0.14 \\
\hline & 1998 & 1.10 & 0.65 & -0.84 & -0.30 & -0.07 \\
\hline & 2000 & 1.03 & 0.64 & -0.92 & -0.57 & -0.01 \\
\hline & 2002 & 1.13 & 0.71 & -0.85 & -0.51 & 0.07 \\
\hline & 2003 & 0.91 & 0.83 & -0.84 & -0.49 & 0.06 \\
\hline & 2004 & 0.83 & 0.87 & -0.62 & -0.46 & 0.04 \\
\hline & 2005 & 0.89 & 0.85 & -0.87 & -0.60 & 0.06 \\
\hline \multirow[t]{5}{*}{ Govt. Effective. } & 1996 & 1.68 & 0.63 & -1.20 & -0.48 & -0.25 \\
\hline & 1998 & 1.66 & 0.52 & -0.96 & -0.51 & -0.30 \\
\hline & 2000 & 1.74 & 0.58 & -0.89 & -0.55 & -0.16 \\
\hline & 2002 & 1.70 & 0.57 & -0.90 & -0.63 & -0.21 \\
\hline & 2003 & 1.66 & 0.61 & -0.92 & -0.62 & -0.21 \\
\hline
\end{tabular}




\begin{tabular}{lllllll} 
& 2004 & 1.68 & 0.59 & -0.88 & -0.62 & -0.17 \\
\hline Reg. Quality & 2005 & 1.64 & 0.75 & -1.02 & -0.67 & -0.13 \\
& 1996 & 1.30 & 0.85 & -1.01 & -0.44 & -0.02 \\
& 1998 & 1.24 & 0.80 & -0.81 & -0.44 & -0.08 \\
& 2000 & 1.34 & 0.74 & -0.84 & -0.42 & -0.11 \\
& 2002 & 1.42 & 0.87 & -0.97 & -0.55 & -0.07 \\
& 2003 & 1.39 & 0.84 & -0.88 & -0.56 & -0.11 \\
& 2004 & 1.44 & 0.83 & -0.89 & -0.53 & -0.09 \\
\hline Rule of Law & 2005 & 1.44 & 0.93 & -1.07 & -0.57 & -0.13 \\
& 1996 & 1.45 & 0.75 & -1.01 & -0.49 & -0.26 \\
& 1998 & 1.46 & 0.62 & -0.87 & -0.53 & -0.31 \\
& 2000 & 1.46 & 0.68 & -0.96 & -0.62 & -0.20 \\
& 2002 & 1.40 & 0.67 & -0.96 & -0.66 & -0.27 \\
& 2003 & 1.41 & 0.62 & -0.98 & -0.61 & -0.29 \\
& 2004 & 1.44 & 0.80 & -1.10 & -0.69 & -0.23 \\
& 2005 & 1.46 & 0.70 & -1.02 & -0.73 & -0.27 \\
\hline Control of Cor. & 1996 & 1.54 & 0.54 & -0.93 & -0.47 & -0.23 \\
& 1998 & 1.48 & 0.53 & -0.89 & -0.58 & -0.24 \\
& 2000 & 1.50 & 0.70 & -0.85 & -0.69 & -0.36 \\
& 2002 & 1.50 & 0.76 & -0.91 & -0.75 & -0.29 \\
& 2003 & 1.43 & 0.83 & -0.87 & -0.69 & -0.30 \\
& 2004 & 1.36 & 0.82 & -0.85 & -0.60 & -0.28 \\
& 2005 & 1.50 & 0.80 & -0.87 & -0.68 & -0.32 \\
\hline
\end{tabular}

Below is a list of the groups with their abbreviations:

H-OECD: High-Income OECD Countries

H-NonOECD: High-Income Non-OECD Countries

Low: Low Income Countries

LowerMiddle: Lower-Middle Income Countries

UpperMiddle: Upper-Middle Income Countries

For our empirical tests in the next section, we use the Mann-Whitney-Wilcoxon test. First, in order to determine whether OECD membership affects the impact of the crisis on governance, we compare High-Income OECD countries and High-Income Non-OECD countries. Then, in order to determine whether the income level of a country affects the impact of the crisis on governance, we compare each income-level group to the next income-level group.

\section{Results}

Figures 1 through 6 present the group governance data shown in Table 1 graphically. Figure 1 shows that, for "Voice and accountability", from 1996 to 2005, the rankings did not change. The High-Income OECD Countries has the highest ranking in "Voice and accountability". The High-Income Non-OECD, the Upper-Middle Income, 
the Lower-Middle income, and the Low Income Countries follow them in that order in 1996 and also in 2005.

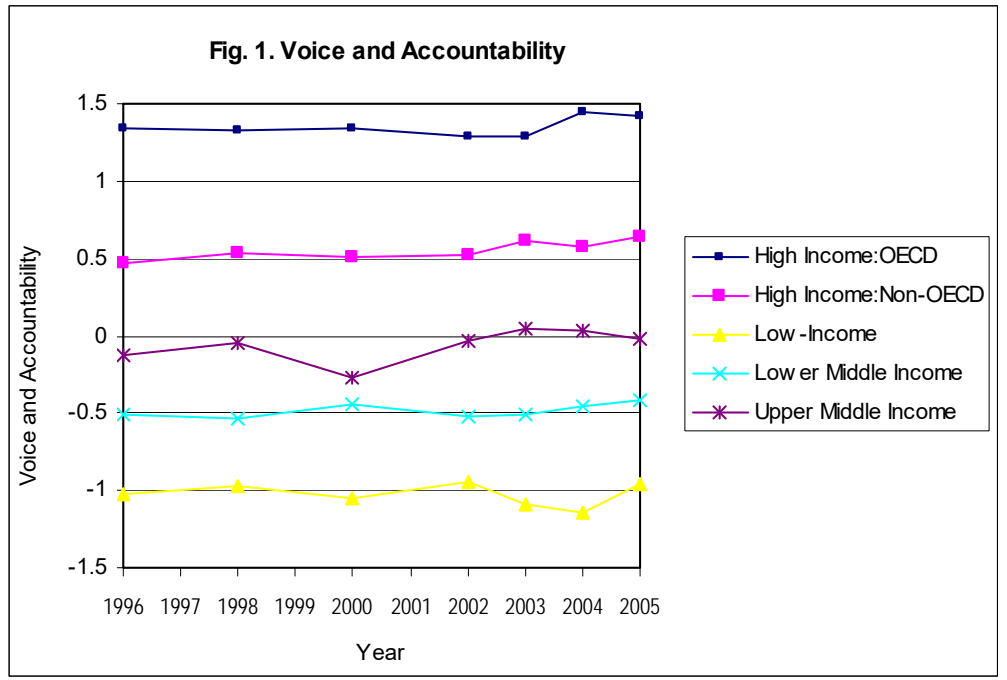

Figure 2 shows that, for "Political stability and absence of violence", over the same time period, the High-Income Non-OECD Countries surpassed the High-Income OECD Countries for a short period of time. In 2005, the two groups are almost equal. The rankings of the other groups did not change although we are noticing an improvement in the Upper-Middle Income Countries.

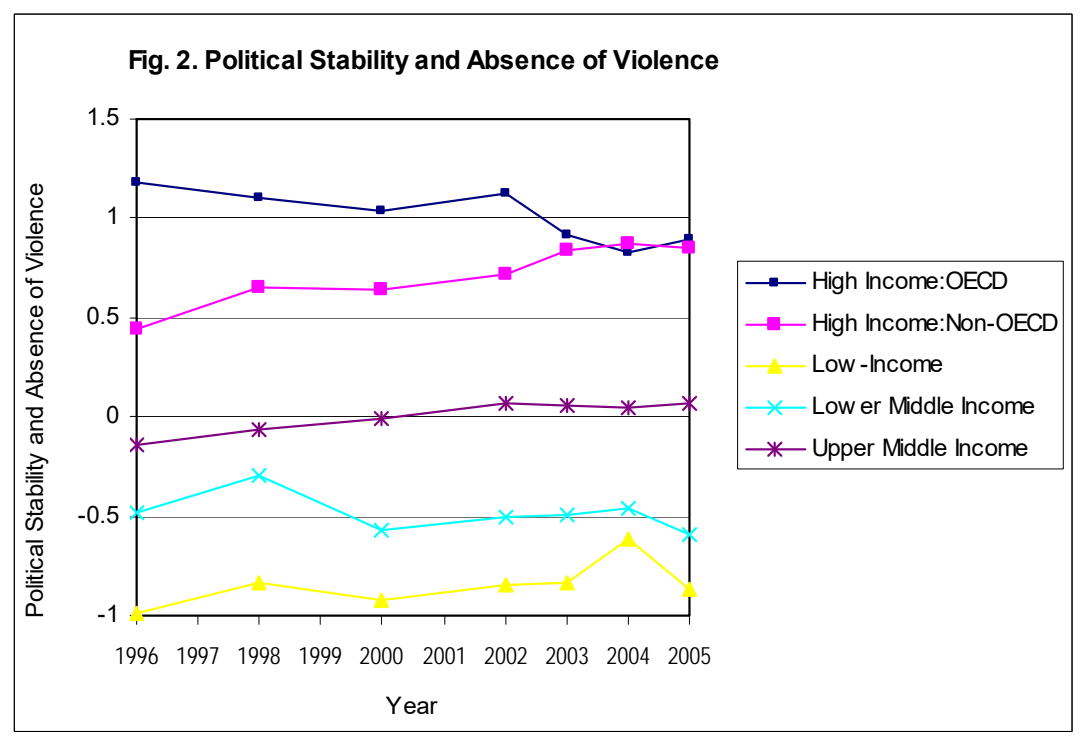

Figure 3 shows that, for "Government effectiveness", from 1996 to 2005, the rankings did not change. The High-Income OECD Countries has the highest ranking. 
The High-Income Non-OECD, the Upper-Middle Income, the Lower-Middle income, and the Low Income Countries follow them in that order in 1996 and also in 2005.

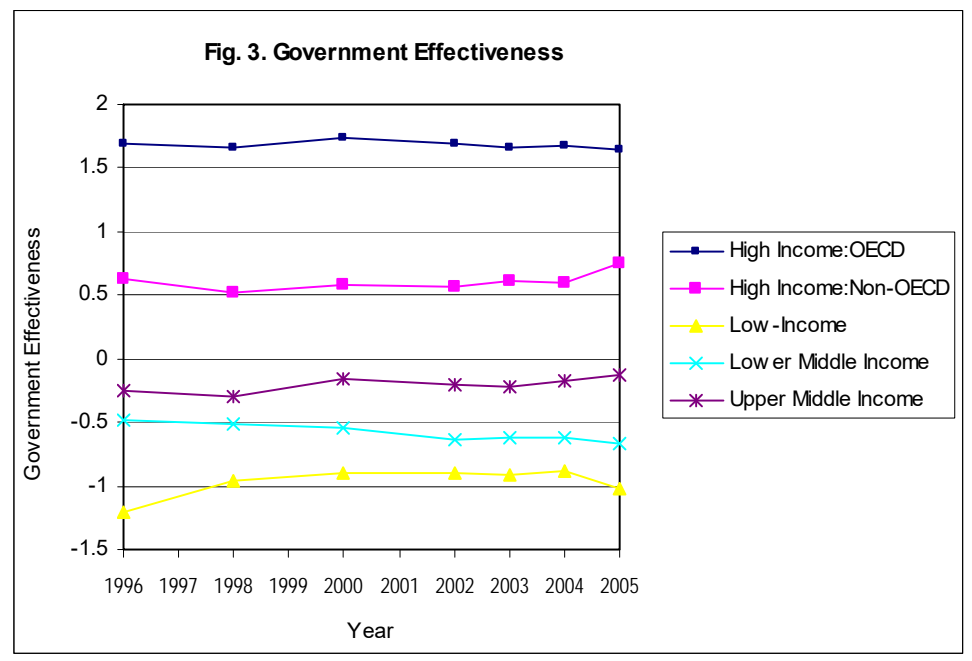

Figure 4 shows that, for "Regulatory quality", from 1996 to 2005, the rankings did not change. The High-Income OECD Countries has the highest ranking. The HighIncome Non-OECD, the Upper-Middle Income, the Lower-Middle income, and the Low Income Countries follow them in that order in 1996 and also in 2005. We are noticing some improvement in the High-Income OECD Countries.

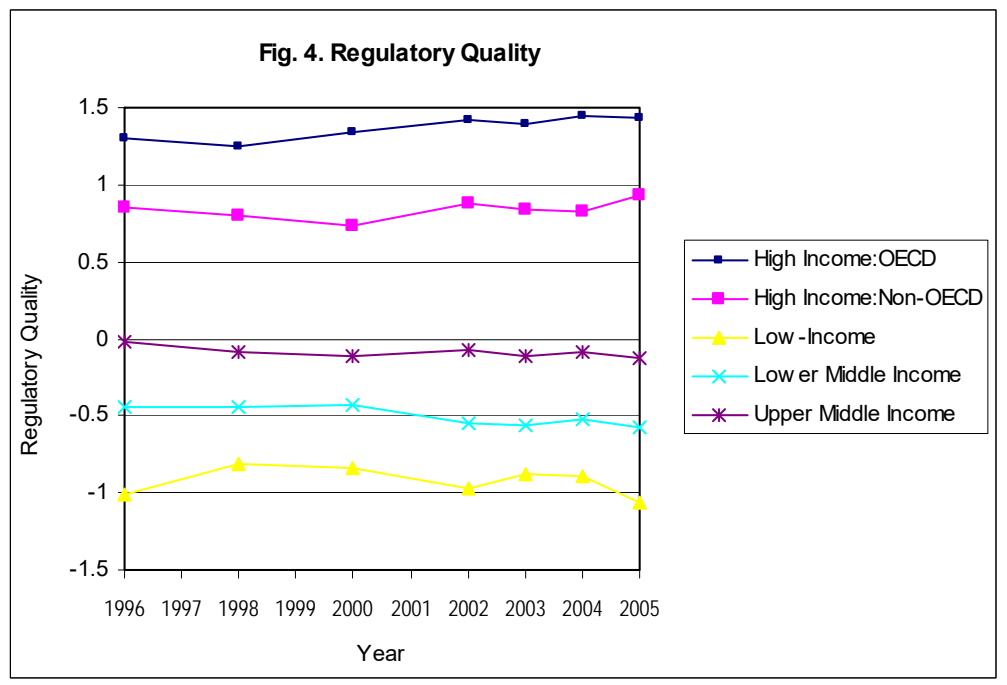

Figure 5 shows that, for "Rule of law", from 1996 to 2005, the rankings did not change. The High-Income OECD Countries has the highest ranking. The High-Income Non-OECD, the Upper-Middle Income, the Lower-Middle income, and the Low Income 
Countries follow them in that order in 1996 and also in 2005. We are noticing a decline in the Lower-Middle Income Countries.

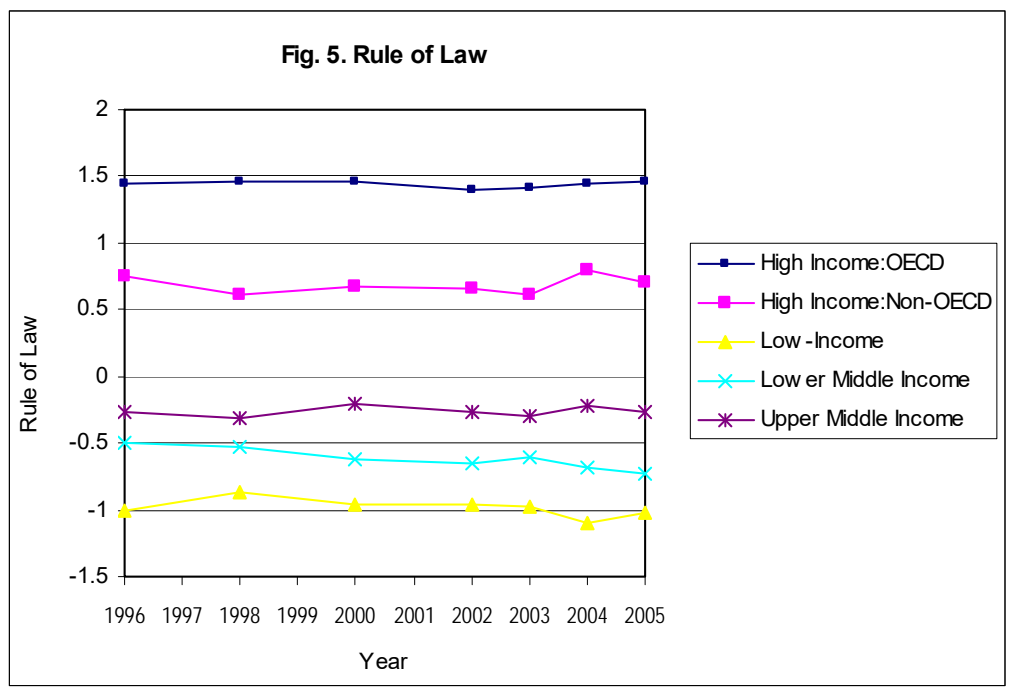

Finally, Figure 6 shows that, for "Control of corruption", from 1996 to 2005, the rankings did not change. The High-Income OECD Countries has the highest ranking. The High-Income Non-OECD, the Upper-Middle Income, the Lower-Middle income, and the Low Income Countries follow them in that order in 1996 and also in 2005. We are noticing an improvement in both the High-Income Non-OECD Countries and the Low Income Countries. We are also noticing a decline in the Lower-Middle Income Countries.

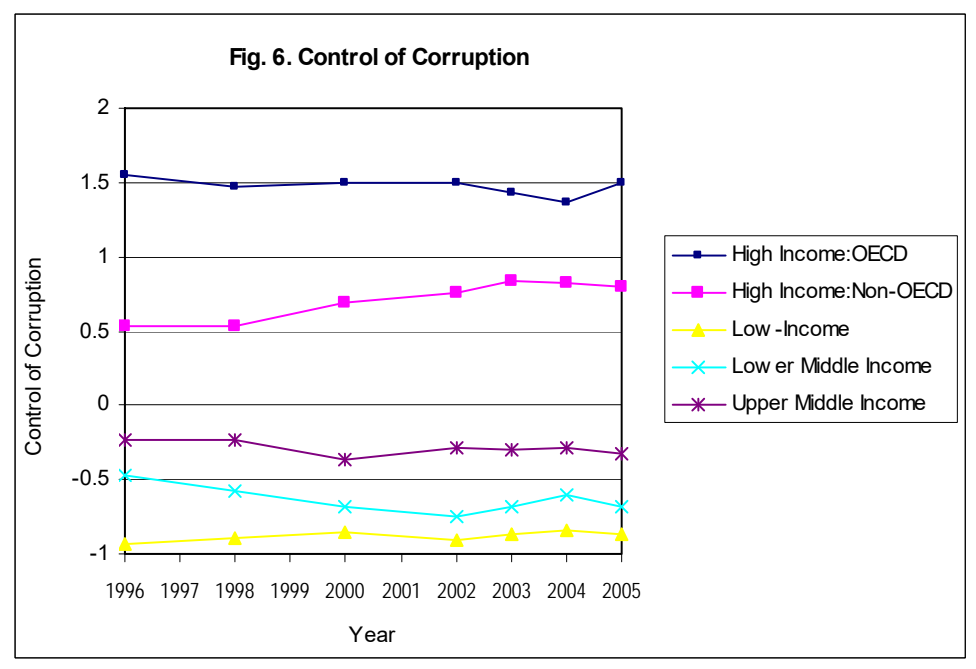

To summarize, we are seeing that the High-Income Non-OECD Countries performed much better than the other groups after year 1998. After 1998, this group 
improved in all six dimensions of governance. On the other hand, the rankings of each income group did not change throughout the period.

Table 2 shows the results of the pre-Asian Crisis and post-Asian Crisis tests that compare the six governance variables in High Income OECD countries versus in High Income Non-OECD countries. Panel A shows the results for the pre-Asian Crisis period and Panel $B$ shows the results for the post- Asian Crisis period.

Table 2. High Income OECD vs High Income Non-OECD Countries

\begin{tabular}{|c|c|c|c|c|c|}
\hline \multicolumn{6}{|l|}{ Panel A. Year 1996} \\
\hline \multirow[b]{2}{*}{ Variable } & \multicolumn{2}{|c|}{ H-OECD } & \multicolumn{2}{|c|}{ H-NonOECD } & \multirow{2}{*}{$\begin{array}{l}\text { Mann-W. } \\
\text { sig. }\end{array}$} \\
\hline & Mean & Med. & Mean & Med. & \\
\hline Voice and Accountability & 1.27 & 1.35 & 0.39 & 0.47 & $* * *$ \\
\hline Political Stability & 0.98 & 1.18 & 0.42 & 0.44 & $* \star *$ \\
\hline Govt. Effectiveness & 1.43 & 1.68 & 0.66 & 0.63 & $* * *$ \\
\hline Regulatory Quality & 1.26 & 1.30 & 0.71 & 0.85 & $* * *$ \\
\hline Rule of Law & 1.34 & 1.45 & 0.53 & 0.75 & $* \star *$ \\
\hline Control of Corruption & 1.45 & 1.54 & 0.47 & 0.54 & $* * *$ \\
\hline \multicolumn{6}{|l|}{ Panel B. Year 2004} \\
\hline & \multicolumn{2}{|c|}{ H-OECD } & \multicolumn{2}{|c|}{ H-NonOECD } & Mann-W. \\
\hline Variable & Mean & Med. & Mean & Med. & sig. \\
\hline Voice and Accountability & 1.37 & 1.45 & 0.36 & 0.58 & $* \star *$ \\
\hline Political Stability & 0.74 & 0.83 & 0.67 & 0.87 & \\
\hline Govt. Effectiveness & 1.55 & 1.68 & 0.59 & 0.59 & $* * *$ \\
\hline Regulatory Quality & 1.39 & 1.44 & 0.70 & 0.83 & $* * *$ \\
\hline Rule of Law & 1.38 & 1.44 & 0.63 & 0.80 & $* * *$ \\
\hline Control of Corruption & 1.45 & 1.36 & 0.63 & 0.82 & $* * *$ \\
\hline
\end{tabular}

Panel A shows that, before the crisis (i.e. 1996), High Income OECD countries had better scores compared to High Income Non-OECD countries in all six governance variables. The median values of "Voice and Accountability", "Political Stability", "Govt. Effectiveness", "Regulatory Quality", "Rule of Law", and "Control of Corruption" scores are 1.35, 1.18, 1.68, 1.30, 1.45, and 1.54 for High Income OECD countries while the corresponding values are $0.47,0.44,0.63,0.85,0.75$, and 0.54 for High Income NonOECD countries (all of the differences are significant at $1 \%$ level).

Panel B results are similar to Panel A results except for "Political Stability". Panel B shows that, after the crisis, High Income OECD countries still had better scores compared to High Income Non-OECD countries in "Voice and Accountability", "Govt. Effectiveness", "Regulatory Quality", "Rule of Law", and "Control of Corruption". Again, all of the differences are significant at $1 \%$ level. The interesting result here is this: After the crisis, High Income Non-OECD countries had a slightly higher median 
score in "Political Stability" when compared to High Income OECD countries (although the difference is not significant).

When we look at High Income OECD countries' scores pre- and post-crisis, we see that these countries had improved in only two out of six governance variables after the crisis when compared to pre-crisis. For example, while the median "Voice and Accountability" score for these countries is 1.35 pre-crisis, it is 1.45 post-crisis. While their median "Regulatory Quality" score is 1.30 pre-crisis, it is 1.44 post-crisis. For these countries, all other governance variables (i.e. "Govt. Effectiveness", "Political Stability", "Rule of Law", and "Control of Corruption") either declined or stayed at the same level.

On the other hand, when we look at High Income Non-OECD countries, we see that they had improved in four measures (i.e. "Voice and Accountability", "Political Stability", "Rule of Law", and "Control of Corruption") after the crisis when compared to pre-crisis. Hence we conclude that while High Income Non-OECD countries improved in four categories, High Income OECD countries improved in only two categories. Especially, High Income Non-OECD countries' improvement in "Political Stability" is impressive (i.e. from a median score of 0.44 to 0.87 ). This difference between the two groups' performance during and after the crisis explain how High Income Non-OECD countries surpassed High Income OECD countries in "Political Stability" after the crisis.

Table 3 shows the results of the pre-Asian Crisis and post-Asian Crisis tests that compare the six governance variables in High Income Non-OECD countries versus in Upper Middle Income countries. Panel A shows the results for the pre-crisis period and Panel $B$ shows the results for the post-crisis period.

Table 3. High Income Non-OECD vs Upper Middle Income Countries

\begin{tabular}{|c|c|c|c|c|c|}
\hline \multicolumn{6}{|l|}{ Panel A. Year 1996} \\
\hline \multirow[b]{2}{*}{ Variable } & \multicolumn{2}{|c|}{ H-NonOECD } & \multicolumn{2}{|c|}{ UpperMiddle } & \multirow{2}{*}{$\begin{array}{l}\text { Mann-W. } \\
\text { sig. }\end{array}$} \\
\hline & Mean & Med. & Mean & Med. & \\
\hline Voice and Accountability & 0.39 & 0.47 & -0.13 & -0.13 & $* * *$ \\
\hline Political Stability & 0.42 & 0.44 & -0.17 & -0.14 & $* * *$ \\
\hline Govt. Effectiveness & 0.66 & 0.63 & -0.26 & -0.25 & $* * *$ \\
\hline Regulatory Quality & 0.71 & 0.85 & -0.19 & -0.02 & $* * *$ \\
\hline Rule of Law & 0.53 & 0.75 & -0.26 & -0.26 & $* * *$ \\
\hline Control of Corruption & 0.47 & 0.54 & -0.27 & -0.23 & $* * *$ \\
\hline \multicolumn{6}{|l|}{ Panel B. Year 2004} \\
\hline & \multicolumn{2}{|c|}{ H-NonOECD } & \multicolumn{2}{|c|}{ UpperMiddle } & Mann-W. \\
\hline Variable & Mean & Med. & Mean & Med. & sig. \\
\hline Voice and Accountability & 0.36 & 0.58 & -0.14 & 0.03 & $* * *$ \\
\hline Political Stability & 0.67 & 0.87 & -0.03 & 0.04 & $* * *$ \\
\hline Govt. Effectiveness & 0.59 & 0.59 & -0.26 & -0.17 & $* * *$ \\
\hline Regulatory Quality & 0.70 & 0.83 & -0.24 & -0.09 & *** \\
\hline Rule of Law & 0.63 & 0.80 & -0.23 & -0.23 & $* * *$ \\
\hline Control of Corruption & 0.63 & 0.82 & -0.25 & -0.28 & $* * *$ \\
\hline
\end{tabular}


Both pre- and post-crisis, we are seeing that High Income Non-OECD countries had significantly better scores in all six categories when compared to Upper Middle Income countries. In fact, all of the median governance scores for Upper Middle Income countries are negative before the crisis, and four of the median scores for these countries are negative after the crisis. To summarize, in all six governance categories, High Income Non-OECD countries have significantly higher scores (i.e. all differences are significant at $1 \%$ level) when compared to Upper Middle Income countries both pre- and post-crisis.

One point to note here: the ranking between High Income Non-OECD countries and Upper Middle Income countries did not change after the crisis in any of the six categories. In all six categories, High Income Non-OECD countries had better scores both pre- and post-crisis.

Table 4 shows the results of the pre-Asian Crisis and post-Asian Crisis tests that compare the six governance variables in Upper Middle Income countries versus in Lower Middle Income countries. Panel A shows the results for the pre-crisis period and Panel B shows the results for the post-crisis period.

Both pre- and post-crisis, we are seeing that Upper Middle Income countries had significantly better scores in all six categories when compared to Lower Middle Income countries. To summarize, in all six governance categories, Upper Middle Income countries have significantly higher scores when compared to Lower Middle Income countries both pre- and post-crisis.

Table 4. Upper Middle vs Lower Middle Income Countries

\begin{tabular}{|c|c|c|c|c|c|}
\hline \multicolumn{6}{|l|}{ Panel A. Year 1996} \\
\hline \multirow[b]{2}{*}{ Variable } & \multicolumn{2}{|c|}{ UpperMiddle } & \multicolumn{2}{|c|}{ LowerMiddle } & \multirow{2}{*}{$\begin{array}{l}\text { Mann-W. } \\
\text { sig. }\end{array}$} \\
\hline & Mean & Med. & Mean & Med. & \\
\hline Voice and Accountability & -0.13 & -0.13 & -0.46 & -0.51 & ** \\
\hline Political Stability & -0.17 & -0.14 & -0.51 & -0.48 & ** \\
\hline Govt. Effectiveness & -0.26 & -0.25 & -0.53 & -0.48 & $* \star$ \\
\hline Regulatory Quality & -0.19 & -0.02 & -0.55 & -0.44 & $* * *$ \\
\hline Rule of Law & -0.26 & -0.26 & -0.50 & -0.49 & * \\
\hline Control of Corruption & -0.27 & -0.23 & -0.59 & -0.47 & ** \\
\hline \multicolumn{6}{|l|}{ Panel B. Year 2004} \\
\hline & \multicolumn{2}{|c|}{ UpperMiddle } & \multicolumn{2}{|c|}{ LowerMiddle } & Mann-W. \\
\hline Variable & Mean & Med. & Mean & Med. & sig. \\
\hline Voice and Accountability & -0.14 & 0.03 & -0.52 & -0.45 & $* * *$ \\
\hline Political Stability & -0.03 & 0.04 & -0.49 & -0.46 & $* * *$ \\
\hline Govt. Effectiveness & -0.26 & -0.17 & -0.62 & -0.62 & $* * *$ \\
\hline Regulatory Quality & -0.24 & -0.09 & -0.62 & -0.53 & $* * *$ \\
\hline Rule of Law & -0.23 & -0.23 & -0.59 & -0.69 & $* * *$ \\
\hline Control of Corruption & -0.25 & -0.28 & -0.63 & -0.60 & $* * *$ \\
\hline
\end{tabular}


The interesting point here is this: The differences between the two groups widened after the crisis. As Panel A shows, for pre-crisis, the difference between the two groups is significant at $1 \%$ level for only "Regulatory Quality". The difference is significant at $5 \%$ level for four variables (i.e. "Voice and Accountability", "Political Stability", "Govt. Effectiveness", and "Control of Corruption"). It is significant at $10 \%$ level for "Rule of Law". On the other hand, Panel B shows that all of the differences are significant at $1 \%$ level.

One point to note here: the ranking between Upper Middle Income countries and Lower Middle Income countries did not change after the crisis in any of the six categories. In all six categories, Upper Middle Income countries had better scores both pre- and post-crisis.

Table 5 shows the results of the pre-Asian Crisis and post-Asian Crisis tests that compare the six governance variables in Lower Middle Income countries versus in Low Income countries. Panel A shows the results for the pre-crisis period and Panel B shows the results for the post-crisis period.

Both pre- and post-crisis, we are seeing that Lower Middle Income countries had significantly better scores in all six categories when compared to Low Income countries. In all six governance categories, Lower Middle Income countries have significantly higher scores when compared to Low Income countries both pre- and post-crisis. Both pre- and post-crisis, the differences between the two groups of countries are significant at $1 \%$ level in "Voice and Accountability", "Govt. Effectiveness", "Regulatory Quality", "Rule of Law", and "Control of Corruption". The only exception here is "Political Stability". The difference between the two groups of countries is significant at $5 \%$ level before the crisis and at $10 \%$ level after the crisis.

We are seeing that the ranking between Lower Middle Income countries and Low Income countries did not change after the crisis in any of the six categories. In all six categories, Lower Middle Income countries had better scores both pre- and postcrisis.

Table 5. Lower Middle vs Low Income Countries

\begin{tabular}{|c|c|c|c|c|c|}
\hline \multicolumn{6}{|l|}{ Panel A. Year 1996} \\
\hline \multirow[b]{2}{*}{ Variable } & \multicolumn{2}{|c|}{ LowerMiddle } & \multicolumn{2}{|l|}{ Low } & \multirow{2}{*}{$\begin{array}{l}\text { Mann-W. } \\
\text { sig. }\end{array}$} \\
\hline & Mean & Med. & Mean & Med. & \\
\hline Voice and Accountability & -0.46 & -0.51 & -1.02 & -1.03 & $* * *$ \\
\hline Political Stability & -0.51 & -0.48 & -0.98 & -0.99 & ** \\
\hline Govt. Effectiveness & -0.53 & -0.48 & -1.13 & -1.20 & $* * *$ \\
\hline Regulatory Quality & -0.55 & -0.44 & -1.04 & -1.01 & $* * *$ \\
\hline Rule of Law & -0.50 & -0.49 & -1.08 & -1.01 & $* * *$ \\
\hline Control of Corruption & -0.59 & -0.47 & -0.85 & -0.93 & $* * *$ \\
\hline \multicolumn{6}{|l|}{ Panel B. Year 2004} \\
\hline & \multicolumn{2}{|c|}{ LowerMiddle } & \multicolumn{2}{|l|}{ Low } & Mann-W. \\
\hline Variable & Mean & Med. & Mean & Med. & sig. \\
\hline Voice and Accountability & -0.52 & -0.45 & -0.94 & -1.14 & $* * *$ \\
\hline Political Stability & -0.49 & -0.46 & -0.90 & -0.62 & * \\
\hline \multicolumn{6}{|c|}{ - 128 - } \\
\hline
\end{tabular}




\begin{tabular}{llllll} 
Govt. Effectiveness & -0.62 & -0.62 & -1.00 & -0.88 & $* * *$ \\
Regulatory Quality & -0.62 & -0.53 & -0.99 & -0.89 & $* * *$ \\
Rule of Law & -0.59 & -0.69 & -1.04 & -1.10 & $* * *$ \\
Control of Corruption & -0.63 & -0.60 & -0.90 & -0.85 & $* * *$ \\
\hline
\end{tabular}

\section{Conclusion}

In this study, we examine the impact of the 1997 Asian Crisis on Governance while allowing for the moderating effects of OECD membership and income levels. As measures of governance, we use World Bank's Worldwide Governance Indicators (i.e. WGI) which includes six dimensions of governance. These six dimensions are "Voice and Accountability", "Political Stability and Absence of Violence", "Government Effectiveness", "Regulatory Quality", "Rule of Law", and "Control of Corruption".

We examine the 1996-2005 period which allows us to compare the indicators before the crisis and many years after the crisis. World Bank classifies countries according to their OECD membership and also according to the country's income levels. We use their classification and focus on five groups of countries. These are High-Income OECD, High-Income Non-OECD, Upper-middle Income, Lower-Middle Income, and Low Income Countries.

Our results show that, pre- and post-crisis, the ranking of each income group has not changed except for year 2004 when the High-Income Non-OECD Countries surpassed the High-Income OECD Countries in "Political Stability and Absence of Violence" category. Other than that exception in 2004, both pre- and post-crisis, the High-Income OECD Countries had the best governance measures, the High-Income Non-OECD Countries had the second best measures, and so on, in the order shown above.

Our results also show that the High-Income Non-OECD Countries performed much better than the other groups after year 1998. After 1998, this group improved in all six dimensions of governance. We conclude that although crises affect all income groups, because of certain characteristics of the High-Income Non-OECD group, they tend to better react to crises.

\section{References}

Desta, A., (2012), Good Growth and Governance in Africa: Implementing Rather than Rethinking Development Strategies, International Journal of Academic Research in Accounting, Finance and Management Sciences, Vol. 2, no. 2, pp. 69-75.

Fleischer, J., and Parrado, S., (2010), Power distribution in ambiguous times: The effects of the financial crisis on executive decision-making in Germany and Spain, der moderne staatZeitschrift für Public Policy, Recht und Management, Vol. 3, no. 2.

Gieve, J., and Provost, C., (2012), Ideas and coordination in policymaking: The financial crisis of 2007-2009, Governance, Vol. 25, no. 1, pp. 61-77. 
Haggard, S., (1999), Governance and growth: lessons from the Asian economic crisis, Asian-Pacific Economic Literature, Vol. 13, no. 2, pp. 30-42.

Higgott, R., (1998), The Asian economic crisis: a study in the politics of resentment, New Political Economy, Vol. 3, no. 3, pp. 333-356.

Jung, Y. D., (2010), Introduction to Symposium on Public Administration and Governance in a Time of Global Economic Turbulence: Searching for New Paradigms, Korean Journal of Policy Studies, Vol. 24, no. 1-2.

Kahler, M., (2013), Economic Crisis and Global Governance: The Stability of a Globalized World, Procedia-Social and Behavioral Sciences, Vol. 77, pp. 55-64.

Kickert, W., (2012), State responses to the fiscal crisis in Britain, Germany and the Netherlands, Public Management Review, Vol. 14, no. 3, pp. 299-309.

Levine, R., (2012), The governance of financial regulation: reform lessons from the recent crisis, International Review of Finance, Vol. 12, no. 1, pp. 39-56.

Li, J. S., (2003), Relation-based versus Rule-based Governance: An Explanation of the East Asian Miracle and Asian Crisis, Review of international economics, Vol. 11, no. 4, pp. 651-673.

Mgonja, B. E. S. and Tundui, C., (2012), Institutional Impacts of the Local Government Reform Program on Good Local Governance in Tanzania, International Journal of Academic Research in Business and Social Sciences, Vol. 2, no. 5, pp. 206-222.

Peters, B. G., Pierre, J., and Randma-Liiv, T., (2011), Global financial crisis, public administration and governance: Do new problems require new solutions? Public Organization Review, Vol. 11, no. 1, pp. 13-27.

Posner, P., and Blöndal, J., (2012), Democracies and deficits: Prospects for fiscal responsibility in democratic nations, Governance, Vol. 25, no. 1, pp. 11-34.

Remmer, K. L., (1990), Democracy and economic crisis: the Latin American experience, World Politics, Vol. 42, no. 03, pp. 315-335.

Woods, N., (2010), Global governance after the financial crisis: a new multilateralism or the last gasp of the great powers? Global Policy, Vol. 1, no. 1, pp. 51-63. 